\title{
Soil or fire: what causes treeless sedgelands in Tasmanian wet forests?
}

\author{
David M. J. S. Bowman • George L. W. Perry
}

Received: 8 June 2017 / Accepted: 12 August 2017 /Published online: 20 September 2017

(C) Springer International Publishing AG 2017

\begin{abstract}
Background Ecologists fiercely debate the role of soil conditions and fire regimes in controlling forest - savanna boundaries. A prominent component of this debate centres on the plausibility and existence of fire-mediated alternative stable state dynamics (FMASS), a model first proposed by the Tasmanian ecologist WD Jackson in 1968. The FMASS model asserts that increased or decreased landscape fire activity, often due to human intervention, can overwhelm physical environmental (e.g. topography and edaphic factors) controls of forest and savanna mosaics, thereby creating landscape dynamism. Many FMASS models include fire-vegetation-soil interactions (FVS), in which changes in fire frequency can change soil fertility and hence tree growth. This interaction, in turn, affects the capacity offorests to recover from disturbance and long unburnt savanna to convert to forest. Scope We evaluate support for the FMASS-FVS model in the context of the dynamics of the Tasmanian forests that have recently been drawn into wider, global debates surrounding the cooccurrence of tree and treeless vegetation states. We develop a simple spatial simulation model to illuminate
\end{abstract}

Responsible Editor: Philippe Hinsinger.

D. M. J. S. Bowman $(\bowtie)$

School of Biological Sciences, University of Tasmania, Private

Bag 55, Hobart 7001, Australia

e-mail: David.Bowman@utas.edu.au

G. L. W. Perry

School of Environment, University of Auckland, Private Bag, Auckland 92019, New Zealand the difficulties in analysing landscape pattern to draw inferences about the existence of FMASS-FVS.

Conclusions Our review of the Tasmanian evidence shows that FMASS-FVS cannot unambiguously explain all tracts of sedgelands in Tasmanian wet forests, and hence Tasmania should not be used as an exemplar of these theories globally. Our simulations highlight that soil sampling that targets forest boundaries risks erroneously concluding that the distribution of forest and savanna boundaries is decoupled from edaphic factors. We describe a structured methodological pathway that can identify the role of FMASS-FVS in Tasmanian forest dynamics, and elsewhere in the world. This approach use cross-scale temporal and spatial analyses, and targeted experimental tests, to illuminate the interplay of fire, vegetation and edaphic factors in controlling tree establishment and growth and forest boundary dynamics.

Keywords Alternative stable states · Australia · Fire ecology · Grassland · Landscape ecology · Rainforest . Savanna $\cdot$ Tree growth rates $\cdot$ Vegetation boundary

\section{Introduction}

Mosaics of forest and savanna (defined here to include graminoid-dominated vegetation with and without a discontinuous tree stratum) are an iconic example of the decoupling of climate from vegetation that has long fascinated ecologists and biogeographers (Beard 1953; Billings and Mark 1957; Webb 1964; Kellman 1975; 
Bowman 2000; McGlone 2001; Perry and Enright 2002; Bond et al. 2005; Bowman and Haberle 2010; Oliveras and Malhi 2016; Langan et al. 2017). A number of biogeographic and ecological theories have been proposed to explain forest - savanna mosaics, broadly championing the primacy of fire regimes (Bowman 2000), soil physical (Beard 1953) and/or chemical (Lloyd et al. 2008) conditions, including some combinations of these edaphic factors (Veenendaal et al. 2015; Langan et al. 2017). These theories are fiercely contested. If forest - savanna boundaries are controlled by topographic and edaphic factors (such as soil drainage, texture, nutrient supply, water holding capacity, rooting depth), then fire disturbance is a secondary effect that acts to sharpen them and reinforce stable mosaics (Kellman 1984; Wilson and Agnew 1992; Wood and Bowman 2012). For instance, Langan et al. (2017) found that dynamic vegetation modelling experiments, designed to evaluate whether interactions among plant rooting depth, fire and precipitation, could predict the occurrence of savanna or forest biome states in tropical South America. Alternatively, if fire disturbance controls forest - savanna mosaics via feedbacks with soil conditions, then edaphic differences are a consequence, rather than the cause, of abrupt boundaries (Staal and Flores 2015; Pellegrini 2016), and slight shifts in fire regime could change the distribution of forest and savanna, making the mosaic meta-stable. This latter view has been formalised by the application of a fire-mediated alternative stable states (FMASS) model that has been developed for flammable landscape types across boreal (e.g. Johnstone et al. 2010), temperate (e.g. Odion et al. 2010) and tropical (e.g. Staver et al. 2011) biomes.

According to FMASS, forest and savanna 'states' are maintained by ecological feedbacks that can be overwhelmed, causing abrupt transitions between the two vegetation types (Warman and Moles 2009; Hirota et al. 2011; Staver et al. 2011). In many, but not all (Beckage et al. 2009; Staver and Levin 2012), FMASS models, fire-vegetation-soil (FVS) interactions explain edaphic differences between forest and savanna (Jackson 1968; Wood and Bowman 2012; Staal and Flores 2015; Pellegrini 2016), underpinning hysteresis in forest - savanna boundary dynamics (Kellman 1984; Staal and Flores 2015; Pellegrini 2016). Severe fire or an abrupt increase in fire frequency can result in rapid forest loss and reduced post-fire soil fertility due to loss of the organic layer, volatilisation of nutrients, long distance transport of ash, leaching and soil erosion (Pivello and Coutinho 1992; Pellegrini et al. 2015; Kettridge et al. 2015; Bowman 2017). Conversely, forest recovery may be much slower due to seed dispersal limitation and/or reduced tree growth rates due to recurrent soil nutrient loss and gradual recovery of nutrient capital (Kellman 1984; Pellegrini 2016).

The broader global debate about the cause of forest savanna mosaics is important because it is central to one of the most important issues in fire ecology: whether or not landscape fire can transform landscapes from a forested to a savanna or treeless state (Bond et al. 2005; Bowman and Haberle 2010). For instance, the South Island of New Zealand has become an iconic example of how colonising humans were able to extremely rapidly transform vast areas of landscapes from dry forest to grassland (McGlone 2001; McWethy et al. 2010), while simultaneously eliminating the avian megafauna (Perry et al. 2014a). This extraordinarily well-dated human colonisation event (Wilmshurst et al. 2008) has been used as an analogue to explain the much less reliably dated marsupial megafaunal extinctions and altered fire regimes thought by some authors to have immediately followed human colonisation of mainland Australia (Miller et al. 2005; Rule et al. 2012; Johnson 2016), an event promoted by Tim Flannery in the landmark environmental history The Future Eaters (Flannery 1994). Environmental history narratives such as The Future Eaters, The Biggest Estate on Earth (Gammage 2011) and Dark Emu (Pascoe 2014) have ingrained in the popular imagination the idea that Aboriginal fire-use fundamentally transformed Australia. Evaluating the ecological legacy of landscape burning by indigenous people is extremely challenging (McWethy et al. 2013; Foreman 2016), but is essential for understanding how current and future human-dominated fire regimes might transform vegetation distributions globally (Johnstone et al. 2016) and the flow-on effects for the carbon cycle and hence anthropogenic climate change (Furley 2010).

The temperate island of Tasmania $\left(41-44^{\circ} \mathrm{S}\right)$, $200 \mathrm{~km}$ to the south of south-eastern Australia, is an ideal model system in which to explore the entwined question of indigenous fire usage in transforming landscapes and FMASS. Tasmania has been used as a casestudy to support the influential concept of 'fire-stick farming' (Jones 1969) and as an exemplar of a landscape skilfully transformed by Aboriginal fire usage (Gammage 2011). WD Jackson's (1968) research on 
Tasmanian forest dynamics is recognised as developing the first model of FMASS globally (Petraitis and Latham 1999). Although Jackson's (1968) model has been widely endorsed by ecologists it is far from universally accepted. Enduring debate has stimulated research into the vegetation dynamics of perhumid Tasmania across numerous disciplines, and this has led to seemingly contradictory conclusions (Thomas et al. 2010; Wood and Bowman 2012). More recently, Jackson's 'ecological drift' model has been drawn into the debate over tropical forest - savanna dynamics (Cochrane et al. 1999; Bowman and Wood 2009; Staal and Flores 2015).

Here we introduce Jackson's ecological drift model of Tasmanian forest dynamics, reviewing the evidence for and against it, including developing a heuristic (exploratory) landscape model. We then describe a structured methodological pathway that can help discriminate between alternative, and competing, models of forest dynamics. Finally, we discuss how Tasmanian research can inform understanding of FMASS elsewhere in the world.

\section{Fire mediated alternative stable state (FMASS) model of Tasmanian landscape dynamics}

Jackson (1968) developed the first model of FMASS globally in an effort to explain the mosaic of highly flammable vegetation types, including treeless sedgelands and shrublands, which can be considered analogous to savanna in FMASS models, juxtaposed with infrequently burnt tall wet eucalypt forests and pyrophobic temperate rainforest, that co-occur in perhumid regions of Tasmania (Figs. 1 and 2). He considered the large tracts of sedgeland (locally known as 'moorlands') to be anomalous given the cool, perhumid temperate climate. Jackson's 'ecological drift' model asserted that each vegetation community has a specific fire frequency shaped by changes in post-fire vegetation-flammability relationships. The sedgeland and shrublands burns frequently (c. 15-30 years), whereas eucalypt forest and rainforest burn infrequently (c. 100 to 500 years). These fire regimes, in turn, are assumed to influence soil development and soil nutrient capital. Hence, positive fire-vegetation-soil feedbacks are assumed to stabilise both vegetation patterns and the fire regime. However, Jackson (1968) argued that chance shifts in fire activity could result in

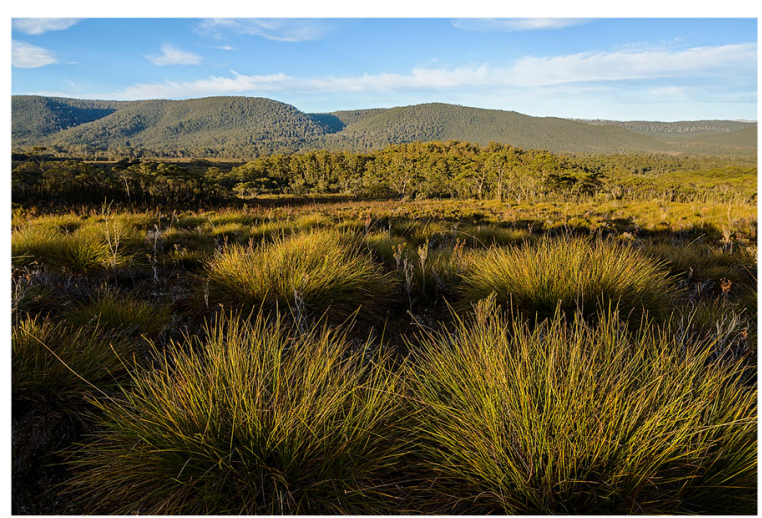

Fig. 1 A western Tasmanian forest - savanna mosaic with treeless sedgeland dominated by Gymnoschoenus sphaerocephalus on a valley floor in foreground and Eucalyptus forest on low ridges and valley slopes in western Tasmania in background. (Photograph Grant Dixon)

vegetation 'state change', and after such shifts new states would be maintained by a different set of stablising feedbacks, particularly increased or decreased soil fertility and vegetation-fire hazards (Wood and Bowman 2012; Fig. 3).

Mount $(1979,1982)$ proposed an alternative model that emphasises topographic and edaphic factors as explaining the landscape ecology of perhumid Tasmania. His model is based on 'stable fire cycles' in which edaphic factors, shaped by geology, drainage, and topography, control vegetation patterns and fire, reinforce these patterns (Fig. 3). Over the last 40 years the debate between the 'ecological drift' and 'stable fire cycles' models has stimulated research considering the vegetation dynamics of perhumid Tasmania in a broad cross-section of disciplines, leading to ongoing debate and presentation of seemingly contradictory conclusions (see reviews of Thomas et al. 2010; Wood and Bowman 2012). Below we briefly review the evidence for and against FMASS and FVS interactions in perhumid Tasmania, as briefly summarised in Table 1 .

Palaeoecology The deglaciation that accompanied the end of the LGM (c. $18 \mathrm{kypb}$ ) resulted in upward shifts in the elevational treeline and rapid expansion of forest across Tasmania (Macphail 1979, 1980). Highresolution palynological analyses in rainforest areas suggest that fire activity and forest dynamics through the Holocene were driven primarily by regional changes in climate (e.g., Fletcher et al. 2014b; Stahle et al. 2016). Palynological studies also indicate that some areas of Tasmania have remained treeless since deglaciation, 

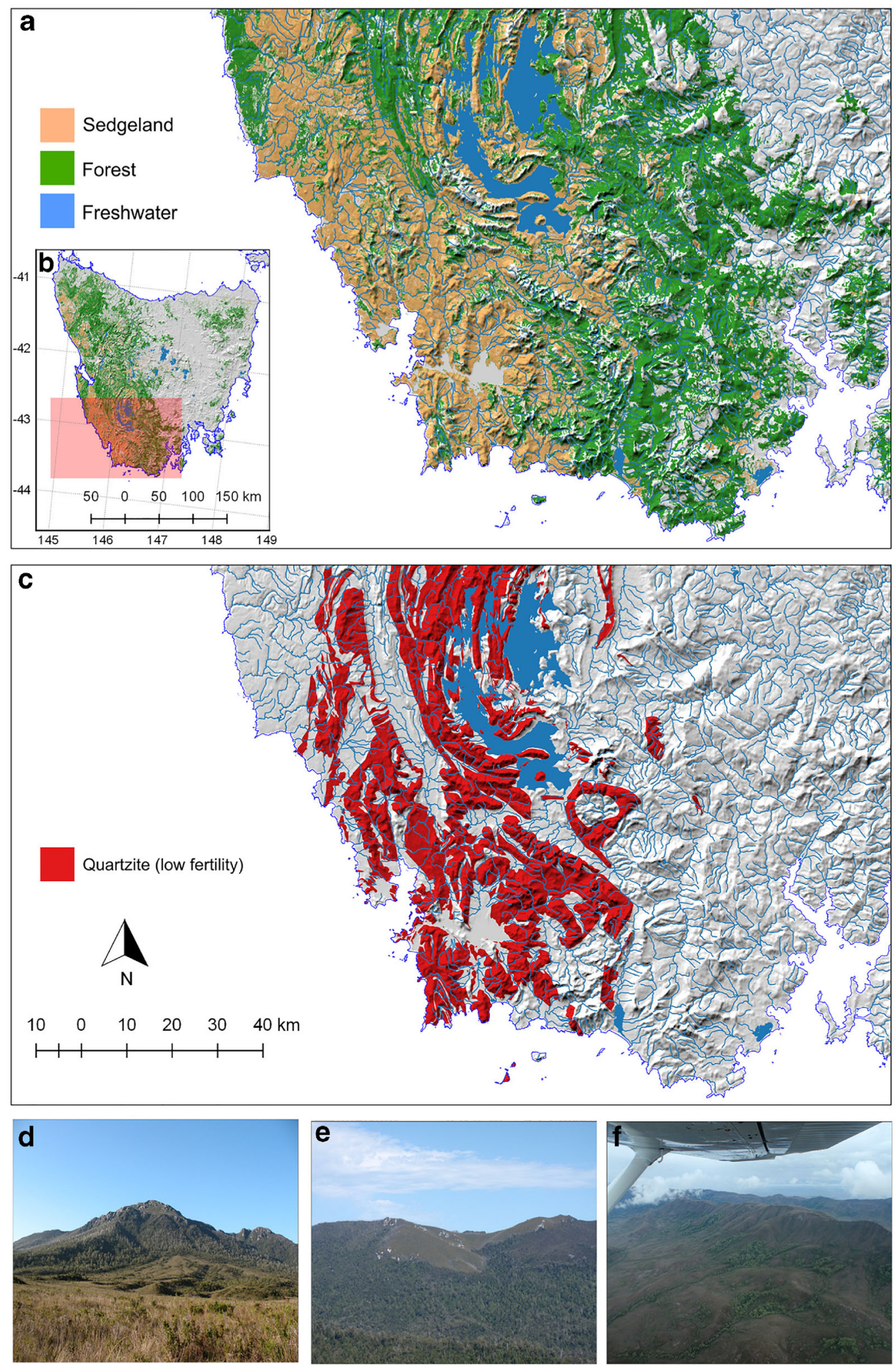
Fig. 2 Distribution of forest and sedgeland in Tasmania. Maps of (a and b) of Tasmania showing the distribution of patches of rainforest and wet eucalypt forest (green) and treeless sedgelands (brown) with area $>100$ ha and (c) the dominant geology of this region. Note the broad concordance of sedgeland with infertile quartzite and forest with more fertile geologies. Map (a) shows a high-resolution map of mosaics (all patches included) and panels (d, e and f) show different types of forest-sedgeland boundaries in SW Tasmania (d- a broad forest-sedgeland boundary, esedgeland embedded in forest and $\mathbf{f}-$ forest embedded in sedgeland). Data sources: TasVeg 3 [http://www.dpipwe.tas.gov. au/tasveg], 1:250,000 scale digital geology of Tasmania [http://www.mrt.tas.gov.au/portal/1-250-000-scale-digitalgeology-of-tasmania], and 7.5 arc-second GMTED-2010 [NASA]

apparently maintained in this state by Aboriginal landscape burning (Fletcher and Thomas 2007, 2010; Colhoun and Shimeld 2012). However, this latter hypothesis has been questioned (Macphail 2010), and vegetation reconstruction from the same location (Cradle Mountain) has led to conflicting interpretations of the relative importance of Holocene climate change (e.g., Stahle et al. 2016) and Aboriginal fire management (Mariani et al. 2017). Localised and abrupt firedriven switches from forest to sedgeland due to changed fire regimes are also apparent in the palaeoecological record (Podger et al. 1988; Fletcher et al. 2014b), although the underlying causes of the origination and maintenance of these switches remains unclear. In sum, the palaeoecological data show regional climate control of fire-driven vegetation change, with some localised changes that appear independent of climate and possibly caused by human fire-use.

Landscape ecology Parent material and terrain strongly influence the spatial extent of sedgelands, shrubland and forests in Tasmania (Brown 1996). Forest is dominant on comparatively fertile dolerite and limestonederived soils, whereas sedgelands dominate on infertile quartzite and schists (Fig. 2a and c). Landscape-level analyses show a clear effect of landscape context, with forest tending to occur on leeward slopes and valleys and sedgelands occurring on plains and windward slopes (Wood et al. 2011a). Using geospatial modelling, Wood et al. (2011a) demonstrated that the probability of fire occurrence varies with landscape setting, resulting in a self-reinforcing pattern such that landscape fire is channelled across flammable sedgelands but rarely affects forest. The strongly contrasting flammability of forest and sedgelands under moderate fire conditions reinforces these effects (Marsden-Smedley et al. 2001). The association of forest with well-drained valley slopes suggests that soil drainage and aeration likely affect tree growth
Fig. 3 Fire-vegetation soil feedbacks. a Conceptual diagram showing the potential interactions between vegetation, fire and soil that can theoretically result in stable mosaics of forest and savanna (after Staal and Flores 2015) (b) and (c) Stabilising feedbacks where fire regimes interact with soil conditions (physico-chemical), vegetation flammability and tree establishment and hence maintain forest or savanna, respectively (after Wood and Bowman 2012; Fletcher et al. 2014b)

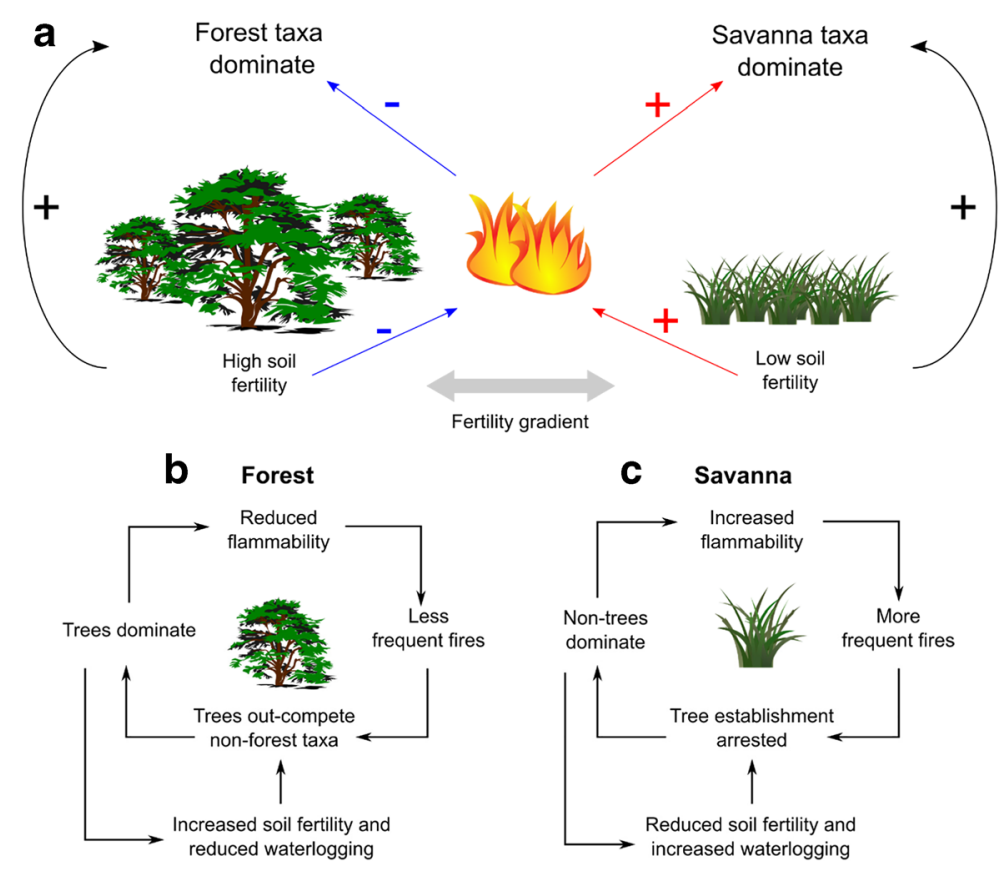


Table 1 Summary of the published evidence for and against FMASS controlling the distribution of forest and sedgeland western Tasmania. See text for more detailed discussion and supporting citations

- Palaeoecology - Available data show predominance of regional climate control of fire-driven vegetation change since the late-Pleistocene with some localised changes that appear independent of climate, and possibly caused by human fire-usage.

- Landscape ecology - Regional and landscape-level patterns of forest and sedgeland affect fire patterns, and both are correlated to geological substrate and geomorphological setting.

- Soil and vegetation patterns - Sedgeland organic soils are typically less fertile and have contrasting physically different characteristics from forest soils but this discrimination is imperfect, with cases where forest and sedgeland occur on the same soil type.

- Effects of fire on soils - Fire can destroy organic sedgeland and forest soils, causing loss of nutrient capital and changes in physical characteristics but these affects can generally be reversed with protection from subsequent fire, with the rate of recovery strongly controlled by the fertility of the parent and geomorphological setting.

- Vegetation dynamics - Forest expansion into sedgelands is restricted to the boundaries between these communities and occurs at decadal to centurial scales suggesting landscape wide changes would occur at millennia time scales. The rate of expansion is controlled by the fertility of parent material and topographic settings that affects fire risk and soil drainage.

- Human fire driven forest dynamics - Available archaeological and ecological research is insufficiently resolved for discriminating whether or not Aboriginal burning is responsible for the extensive tracts of buttongrass moorland western Tasmania. Local studies provide evidence that Aboriginal burning sharpened forest-sedgeland boundaries.

(Wood and Bowman 2012). Localised heterogeneity in soil drainage is believed to explain the scattered occurrence of clumps of trees on poorly drained sedgelands (Macphail et al. 1999; Wood et al. 2011b). Thus, there is clear evidence that geological substrate and geomorphological setting strongly determine both landscape-level fire and vegetation patterns.

Soil patterns A cool climate with year-round precipitation and low evaporation results in the development of deep organic soil horizons under all vegetation types in perhumid Tasmania, even on steep slopes. These organic soils develop very slowly, with basal horizons that date back to the early to mid-Holocene (Macphail et al. 1999; Wood et al. 2011b). There is wide, and overlapping, variation in forest and sedgeland soils' physical and chemical factors (di Folco and Kirkpatrick 2013). For instance, although the concentration and mass of phosphorus and nitrogen are statistically different between forest and sedgeland soils, there are also cases where soil conditions in the two vegetation types overlap (Bowman et al. 1986; Wood and Bowman 2012; Fig. 4). Another feature of these data is that unlike forests there is a near absence of clay in sedgeland soils suggesting the fundamental importance of parent material in pedogenesis (Fig. 4).

Typically, forest - sedgeland boundaries are associated with changes in type and depth of organic soil, often in conjunction with changes in subsoil texture, topographic setting and drainage (Brown and Podger 1982a; Bowman et al. 1986; Wood et al. 2011b; Wood and Bowman 2012). For instance, Wood and Bowman (2012) describe forest on well-drained, shallow fibric soils with basal horizons on sandy loams vs. adjacent sedgeland on deep, poorly drained, sapric soils on gravels and sand. Occasionally, there may be no obvious edaphic discontinuity across forest - sedgeland boundaries (Balmer 1990). In summary, different vegetation types produce different soil types, but there are examples of a decoupling of vegetation type from soil type (Wood and Bowman 2012; di Folco and Kirkpatrick 2013).

Effects of fire on soils Fire can destroy organic soils in sedgelands (Pemberton 1988) and rainforests (Hill 1982). Furthermore, the soil nutrient capital of forests and sedgeland is reduced by fire through volatilisation and transport of ash (Harwood and Jackson 1975; Bowman and Jackson 1981), soil erosion (Wilson 1999; di Folco and Kirkpatrick 2013) and leaching (Bowman and Jackson 1981; Ellis and Graley 1983; Jackson 2000; Fletcher et al. 2014a), and possibly clay eluviation (McIntosh et al. 2005). These impacts are most pronounced on infertile, clay-deficient lithologies, such as quartzite, with much more limited effects on clay-rich soils such as those that develop on dolerite (Ellis and Graley 1983; Jackson 2000). Cyclic salts are an important nutrient input that can rapidly replace nutrients lost as a result of intense forest fires (Ellis and Graley 1983) and, given sufficient time, increase organic soil nutrient capital (Jackson 2000). However, because of changes to soil physical characteristics, especially waterlogging and paludification, the absence of fire may not necessarily create soils suitable for forest growth (Fletcher et al. 2014b).

Vegetation dynamics Eucalypt forest trees have much longer life spans than the 200 years assumed by Jackson 

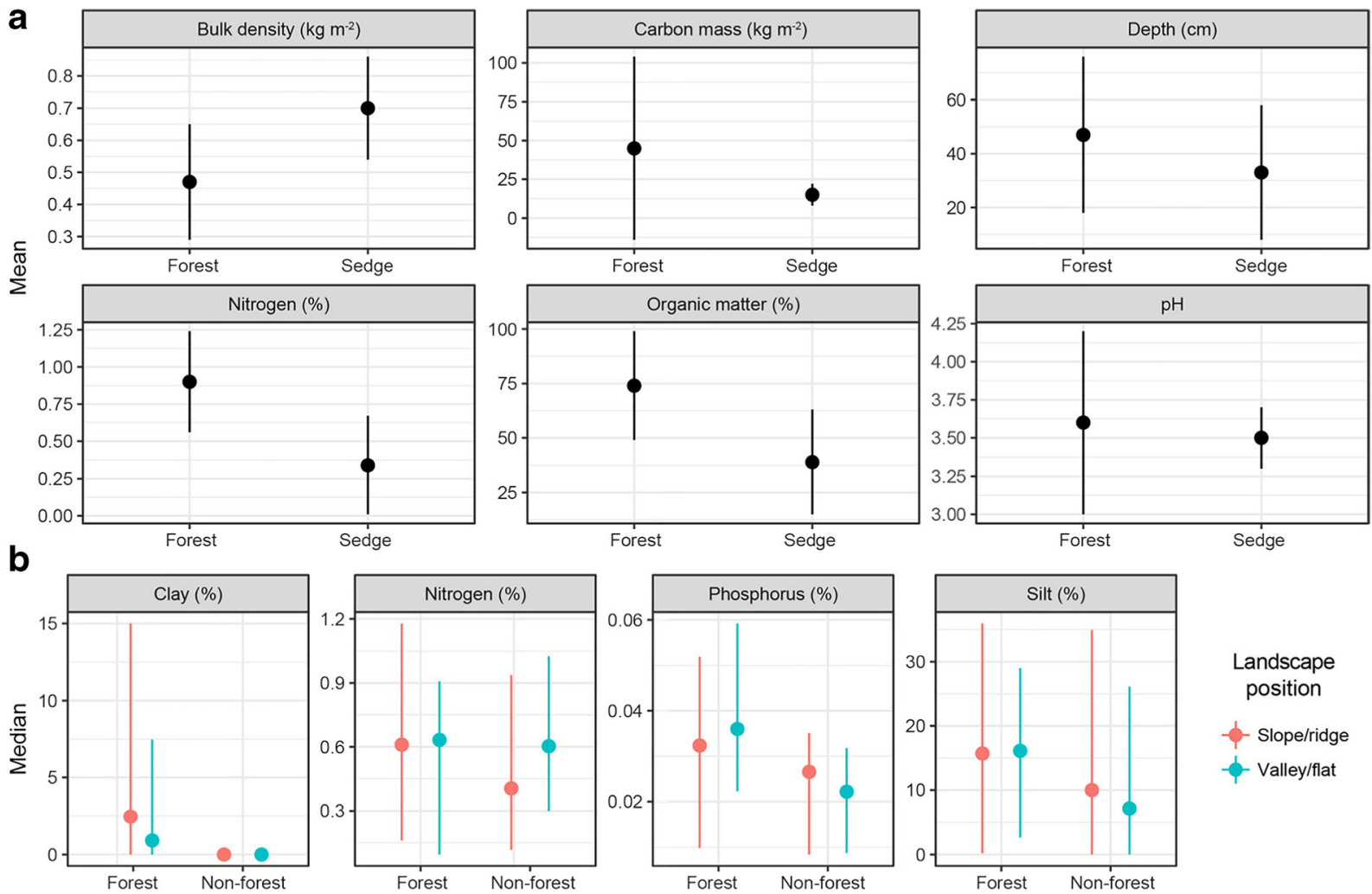

Landscape

position

Slope/ridge

- Valley/flat

Fig. 4 Overlap of soil physical and chemical variables between forest and sedgelands in western Tasmania. Mean and standard deviation of (a) bulk density, carbon mass, soil depth, nitrogen, organic matter and $\mathrm{pH}$ from 434 sedgeland soils and 125 rainforest soil profiless across western Tasmania from data presented in Table 2 of di Folco and Kirkpatrick (2013) and (b) median and

in his model, with emergent trees in early-stage oldgrowth eucalypt forests being dated reliably via tree rings at 500 years (Wood et al. 2010). Such slow growth rates suggest that the rate of conversion of unburnt sedgelands to eucalypt forest over the hundreds of years assumed by Jackson is highly unrealistic, and is actually more likely to occur over millennia, thereby involving consideration of longer term climatic changes such as those that have occurred through the Holocene (e.g., Fletcher et al. 2014a). This inference is supported by analysis of historical aerial photography showing that conversion of sedgelands to forest is extremely slow, and occurs through colonisation of woody pioneer plants (Leptospermum) that form shrublands close to the forest margins (Ellis 1985; Wood and Bowman 2012; Bowman et al. 2013). Repeat field surveys also show that vegetation boundaries are mostly stable on granite, basalt and quartzite substrates, but that localised expansion of Leptospermum shrublands into sedgelands inter-quartile range of clay, nitrogen, phosphorus and silt in upper $10 \mathrm{~cm}$ soil from forest slopes and ridges (52 profiles) and valleys and flats ( 27 profiles) and sedegland slopes and ridges (29 profiles) and valleys and flats (20 profiles) presented in Fig. 6 of Wood and Bowman (2012)

occurs along unburnt forest edges in these settings (Brown et al. 2002; Bowman et al. 2013).

Dendrochronological analysis shows that the chemical fertility of the underlying substrate influences the growth rate of Leptospermum trees into sedgeland. In sedgelands on infertile quartzite substrates, Leptospermum growth rates are extraordinarily slow $(<1 \mathrm{~mm}$ diameter increment per year, French et al. 2016), but are slightly quicker on basalt and granite derived soils (Wood et al. 2016). Leptospermum growth rate declines with increasing distance from forest boundaries possibly due to the combined effects of soil drainage, cold air ponding, grass competition and nutrient limitation (Wood et al. 2016; Fensham and Kirkpatrick 1992). Pot experiments have demonstrated that Leptospermum scoparium growth is strongly constrained by soil drainage (Cook et al. 1980). The slow tree growth in sedgeland environments means that much longer 
fire-free intervals than assumed by Jackson (1968) are required for succession to closed-canopy forests that shadeout the flammable sedgeland layer hence reducing fire risk.

Human fire driven forest dynamics There has been intense debate over the extent to which Aboriginal burning is responsible for the extensive tracts of sedgeland in this perhumid climatic zone (Horton 1982; Bowman and Brown 1986; Cosgrove 1999; Fletcher and Thomas 2010). Some authors have promoted the idea that Aboriginal fire-use merely sharpened existing topoedaphic vegetation patterns (e.g., Horton 1982), whereas others have argued that Aboriginal fire-use created cultural landscapes. The resolution of this debate is severely constrained by the dearth of archaeological sites and research in western Tasmania sedgelands and rainforests. However, a landscape ecological study (Bowman et al. 2013) at one site where intensive archaeological surveys have also been conducted (Murray et al. 1990; Pickering 1992) found that sedgelands were infilling, albeit slowly, with woody vegetation since this disruption of Aboriginal fire-use (Bowman et al. 2013).

The South Island of New Zealand presents an interesting and important contrast to anthropogenic firedriven forest dynamics in Tasmania. Both islands have similar cool temperate forest environments and share many environmental and biogeographic features, including common dominant woody taxa in the Nothofagaceae family (rainforest trees), and the pioneer shrub Leptospermum scoparium (McGlone et al. 2016). Yet these southern hemisphere islands have sharply contrasting histories of human colonisation and fundamentally different fire ecologies with a dearth of fireadapted trees in New Zealand and a preponderance of them in Tasmania (Perry et al. 2014b; Battersby et al. 2017). Because both islands have extraordinarily rich palaeoecological archives it is possible to carefully chronicle the environmental impacts associated with both climate change and human landscape burning. Human colonisation commenced $>35$ thousand years before present $(\mathrm{ka})$ in Tasmania, yet just $0.75 \mathrm{ka}$ in New Zealand. A salient feature of human colonisation of the South Island of New Zealand was the destruction of around $40 \%$ of the forests by anthropogenic burning, concentrated on the drier eastern side of the island (McWethy et al. 2010; Perry et al. 2012). New Zealand researchers have assumed that impacts of Māori fire were negligible in high rainfall areas
(McGlone 1983; Perry et al. 2012), and thus treeless areas in wet forests are edaphically determined and developed before human colonisation. However, in certain high rainfall areas in New Zealand, some patches of open vegetation-which include low Leptospermum shrubland-have been attributed to Māori-era burning (Mark and Smith 1975; Williams et al. 1990; Ogden et al. 2003).

\section{Landscape simulation modelling}

Previous models

A Markov chain analysis (Henderson and Wilkins 1975) of Jackson's model suggests that the predicted cover of different vegetation types broadly matches the proportion observed in the modern-day landscape where underlain by quartzite (Brown and Podger 1982b), but not on more fertile geologies (Brown 1996). Yet as Brown et al. (2002) point out, the concordance of the model prediction for infertile substrates may merely reflect the abundance of fire-protected and fire-prone landscape settings, rather than demonstrating a truly dynamic landscape driven by fire-vegetation-soil interactions. To begin to address this question we have undertaken a spatial simulation modelling exercise instantiating the conceptual models of forest - savanna dynamics proposed by Hoffmann et al. (2012) and Murphy and Bowman (2012).

\section{Simulation model description}

Our simulation model represents the dynamics of the pre-existing interface between forest and savanna (= sedgeland) vegetation, where differences in edaphic factors can affect tree growth rate and hence survival following fire. The model is not intended to represent a specific system although the process it includes and their representation is grounded in empirical information and understanding of the dynamics of the forest - sedgeland systems of western Tasmania. The parameterisation is, therefore, intended to capture forest - savanna systems in a general sense. Such exploratory modelling (sensu Bankes 1993) cannot prove the 'truth' or otherwise of FMASS, rather it has a valuable role in exploring how specific feedbacks and interactions have maintained (as per Petraitis and Latham 1999) 
forest dynamics in western Tasmania. Additionally, this modelling provides insights into the temporal and spatial sampling strategies required to reveal these dynamics. There is a long history of the use of analytical (e.g., Staver and Levin 2012) and simulation (e.g., Batllori et al. 2015) approaches to evaluate the dynamics of the interface between forest and non-forest states. In its implementation our simulation is related to models such as those described by Beckage and Ellingwood (2008) and Accatino et al. (2016), although we do not consider climate and/or tree life-stages or functional type in detail.

We developed a grid-based spatially explicit state and transition model to represent boundary dynamics at a forest - savanna interface. The model was implemented in NetLogo 6.0.1 (Wilensky 1999). Each cell in the landscape can be in either a forest or savanna state, with savanna cells more flammable than forest (as per Marsden-Smedley et al. 2001). At the start of each simulation there is a sharp transition from forest to savanna in the horizontal mid-point of the grid $(200 \times 50$ cells). Fire occurs at a given frequency (average recurrence of $15 \mathrm{y}$ ) and after ignition spreads as a percolation process (O’Sullivan and Perry 2013), with the probability of fire spreading from a burning cell into its unignited neighbour varying depending on the vegetation of the cell being spread into (default of $0.3 \mathrm{vs}$. 0.035 for forest and savanna, respectively). Although the percolation algorithm represents fire spread phenomenologically rather than mechanistically, it is capable of capturing the patterns generated by fires surprisingly well (Zinck and Grimm 2008). All fires start at a randomly selected cell in the savanna state, or if there is no savanna in a randomly selected cell in the forest state. We do not represent inter-annual variability in climate on fire nor the effects of topography, although we acknowledge that these may play a role in FVS and FMASS dynamics. Forest cells transition into the savanna state on burning and savanna cells convert into the forest state after a sufficient period of time has elapsed since they were colonised by a juvenile tree; this elapsed period represents the time required for a juvenile to develop traits that enable it to escape the firetrap (by default $15 \mathrm{y}$ ). Thus, the time to escape the trap is roughly the same as the mean fire interval, which gives the forest a chance to invade the savanna. Each forest cell disperses one propagule per year in a random direction with distance as a random deviate from a negative exponential distribution (mean $=$ one by default). When soil gradients are represented we start with an abrupt transition at the forest - savanna edge, with savanna having a user-defined level of (relative) infertility. Infertility acts to multiplicatively increase the time it takes a colonising tree to escape the fire-trap (e.g., if infertility in savanna is 5.0 (the default) then it will take $5.0 \times 15 \mathrm{y}=75 \mathrm{y}$ for an individual to escape the firetrap). If fire-soil feedbacks are represented then each time that a savanna cell is burned then its infertility increases by 0.2 and each year that a forest cell is unburned its infertility decreases by 0.001 to a minimum of 1.0. Because juvenile individuals are vulnerable to fire, frequent fires can eliminate trees that do not grow quickly enough to escape the 'fire-trap', and, conversely, the absence of fire can allow forest species to colonise the savanna. The effects of soil fertility on tree growth rate are predetermined. The modelling also incorporates temporally asymmetric fire-vegetation-soil feedbacks, whereby gradual soil enrichment occurs in the absence of fire, but soil fertility declines rapidly under frequent fire.

\section{Simulation model experiments}

We use the simulation model to factorially explore four scenarios at forest - savanna boundary dynamics: the presence/absence of a boundary in soil conditions and the presence/absence of fire-soil fertility feedbacks. In all scenarios the fire regime has been selected to enable a forest to slowly invade a savanna (i.e. fire recurrence is similar to time required for an individual to reach fire immunity); under any higher fire frequencies savanna is favoured. The FVS feedbacks in scenarios iii and iv are time asymmetric because fire instantaneously decreases soil fertility, but recovery of soil fertility is gradual. This feedback amplifies the strength of the edaphic effect on woody plant growth. The edaphic gradient in scenarios iii and iv are designed to reduce the growth-rate of the woody plants in savanna so it takes longer for individuals to become fire-tolerant in savanna.

Our modelling clearly shows that the dynamism or stability of a forest - savanna boundary is strongly shaped by the interplay between site productivity, firesoil feedbacks and the establishment and growth of tree species (Fig. 5). Where there is a negligible soil fertility difference and no FVS interaction, forests are likely to retreat under all but the lowest fire frequencies, leading to savanna dominance (Fig. 5 [i]). The scenario with 
a pre-existing soil fertility gradient but no FVS feedback resulted in stable forest - savanna boundaries, albeit with an imperfect correspondence between soil discontinuity and vegetation boundary (Fig. 5 [ii]). Such a scenario conforms to the 'sharpening switch' proposed by Wilson and Agnew (1992). If soil fertility is reduced by fire and slowly increases under forest, abrupt, albeit dynamic, forest - savanna edges can be maintained even in the absence of an initial difference between site productivity (Fig. 5 [iii]) and favour savanna expansion if there is an underlying edaphic gradient (Fig. 5 [iv]). Our modelling indicates that where there is a plant-soil feedback but not one between vegetation and fire then there is a slow drift to forest unless the low fertility soil is an absolute barrier to tree establishment (figure not shown).

This modelling exercise demonstrates the difficulties in using snapshot data, such as that collected at a forest

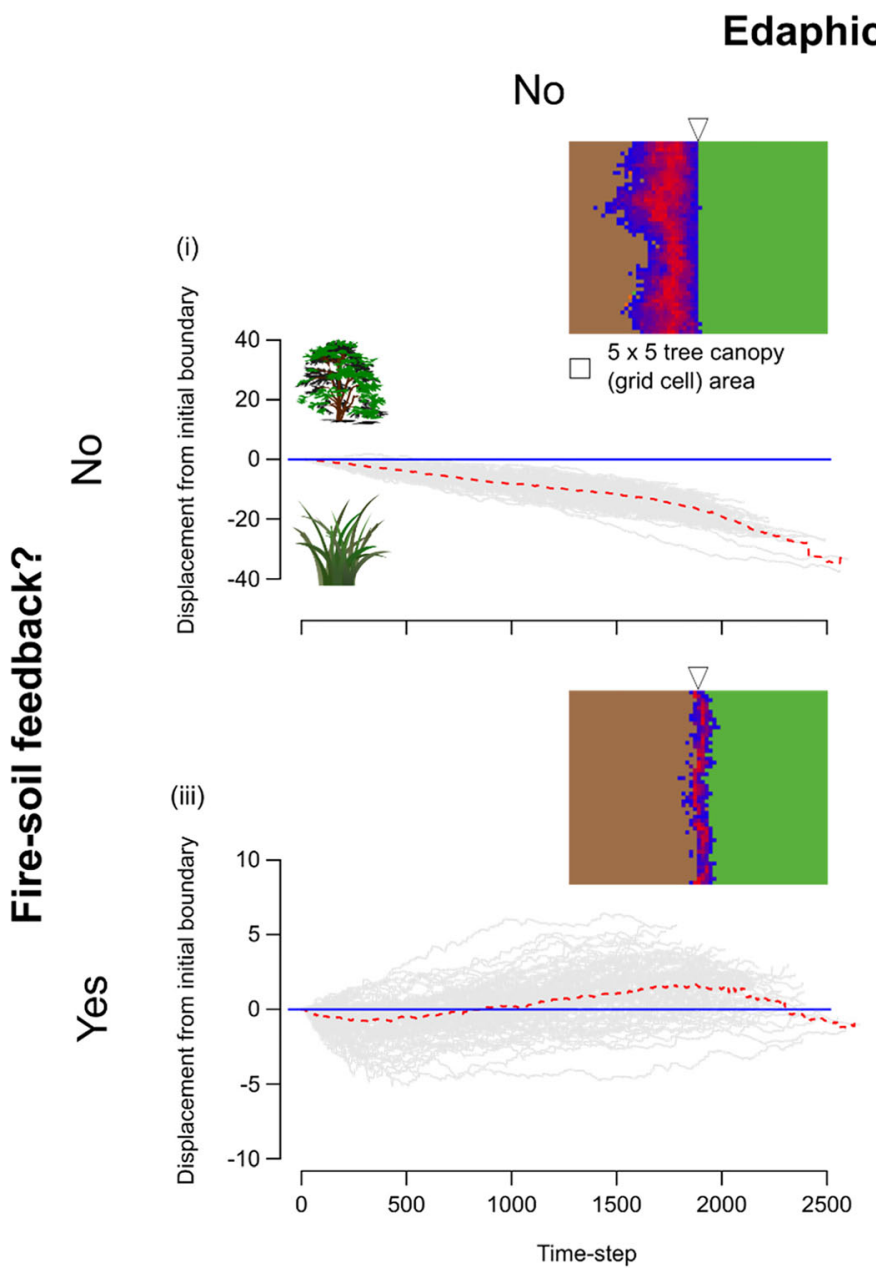

\section{boundary?}

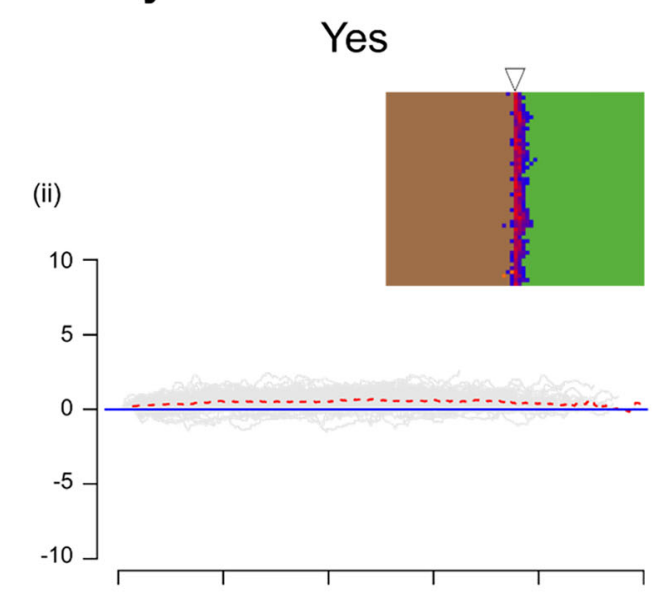

Fig. 5 An exploratory spatial model of the dynamics of an abrupt forest-savanna boundary illustrating four fire-vegetation-soil interaction (FVS) scenarios: (i) no underlying boundary in soil conditions and no fire-vegetation-soil feedback, (ii) boundary in soil conditions without a fire-vegetation-soil feedback, (iii) no boundary in soil conditions but a fire-vegetation-soil feedback and (iv) an abrupt boundary in soil conditions and a fire-vegetation-soil feedback. The graphs show the temporal trajectories of the dynamics over 2500 years ( $n=100$ replicates) for each scenario. Grey lines represent edge dynamics (displacement from original position) for each of $n=100$ simulations, the red line the median of those 100 simulations and the horizontal blue line the original boundary

position. The inset panels show maps of the spatial dynamics of the boundary dynamics over a 2000 year simulation (approximately 120 fires). The blue-red colour scaling indicating the proportion of time a cell has spent in each state (green = always forest, brown = always savanna blue-to-red = low to high dynamism); the hollow triangle indicates the vegetation/soil boundary at the start of the simulation. One grid cell represents an area the size of one typical tree crown. Note plot (i) has different scaling on the yaxis as compared to the other plots. The model source code is available for download at https://figshare.com/s/990c9a615fffc1 bb5a97 
boundary transect, to identify whether fire or site productivity effects, or the interaction between them underpins a forest edge. Even forest - savanna boundaries on abrupt edaphic discontinuities are likely to oscillate, hence at any given point in time the vegetation boundary may not correspond to the underlying edaphic boundary. Thus a single time sequence (the grey lines in Fig. 5) taken from a single location in the hypothetical landscape may provide an erroneous perspective, and at best a partial one. For instance, the historical record at a sharp edaphic boundary may suggest a highly dynamic landscape, whereas a snapshot from a highly dynamic landscape may under-estimate the importance of vegetation change. In short, there is a potential equifinality problem in using pattern to infer process in the context of FVS or FMASS (i.e., the same patterns can arise from different processes; McIntire and Fajardo 2009).

Our modelling suggests that without careful spatiotemporal sampling it is difficult to discriminate between the alternative models of strict edaphic or fire control. Soil and palaeo-ecological sampling must be conducted well away from forest - sedgeland boundaries to avoid spurious inferences about edaphic differences. Sampling close to dynamic boundaries runs the risk of erroneously concluding that there is no edaphic discontinuity where in reality these is a difference. Our modelling therefore supports the conclusion of Warman et al. (2013) that sampling soils close to forest boundaries can lead to fallacious conclusions concerning the role of soil in controlling vegetation mosaics. Using forest and savanna mosaics in north Queensland, these authors demonstrated that to avoid the confounding effects of past dynamics it is necessary to sample savanna and rainforest soils several kilometers from the boundary edge.

\section{Framework to elucidatefire-mediate alternative stable states}

Despite extensive research across disciplines and spanning multiple spatio-temporal extents, current empirical evidence is insufficient to conclusively discriminate between Jackson's (1968) and Mount's (1979) models of vegetation dynamics in perhumid Tasmania (Table 1). This impasse highlights a fundamental problem with the FMASS concept: it is an abstract, deductive model. 'Proving' landscape-level FMASS and FVS models is extremely challenging because of the practical impossibility of evaluating them with classical experimentation
(Petraitis and Latham 1999; Bowman et al. 2015; Oliveras and Malhi 2016; Pausas and Dantas 2016). As with many stable state theories (Petraitis 2013), support for these models has come from correlative evidence and pattern matching, often with very limited statistical replication (May 1977; Staal and Flores 2015; Good et al. 2016); this is an approach that invites conflicting interpretations of system dynamics. To help break this deadlock, we have adapted Bowman et al.'s (2015) conceptual model of the analysis of landscapelevel feedbacks that enables discrimination of the hypotheses that forest - savanna mosaics are best explained by: (a) fire regimes; (b) edaphic patterns; or (c) a combination of both, as predicted by FMASS. Our framework emphasises the integration of the following methodological approaches: (1) Palaeoecological and historical data; (2) Vegetation dynamics; (3) Controls of tree growth rates; and (4) Experimental tests and modelling (Fig. 6).

To support FMASS, reconstructions of fire regimes and vegetation dynamics using palaeocological and historical data must demonstrate that landscape-level fire activity drives dynamism in forest - savanna mosaics during periods of climate stability. Of critical importance is the reconstruction of fire regimes in time and space (Conedera et al. 2009; Iglesias et al. 2015) and convincingly linking fire and vegetation change (e.g., McWethy et al. 2010, 2014). Such reconstructions may include Holocene sedimentary cores (e.g., Behling and Hooghiemstra 2000), analysis of macro subfossil wood or charcoal in soils (e.g., Kellman 1975), geochemical proxies of vegetation types, such as carbon stable isotopes (e.g., Magnusson et al. 2002) and dendrochronological analysis of fire scars across multiple scales (Falk et al. 2011). If such evidence indicates landscape stability across the Holocene and during the historic period, then FMASS can be rejected, with the primary role of edaphic factors in controlling forest - savanna mosaics favoured.

If palaeoecological and historical data demonstrate that forest - savanna mosaics are dynamic, then the next test is to demonstrate that the flux in vegetation types occurs across edaphic and topographic gradients and is driven by fire activity. This test can be achieved by developing separate, independent models to relate fire activity to vegetation patterns. For example, Murphy et al. (2010) used separate geospatial models of fire and Acacia shrubland, which enabled them to conclude that shrublands were restricted to productive 
METHOD

WHAT CONTROLS

FOREST-SAVANNA MOSAICS?

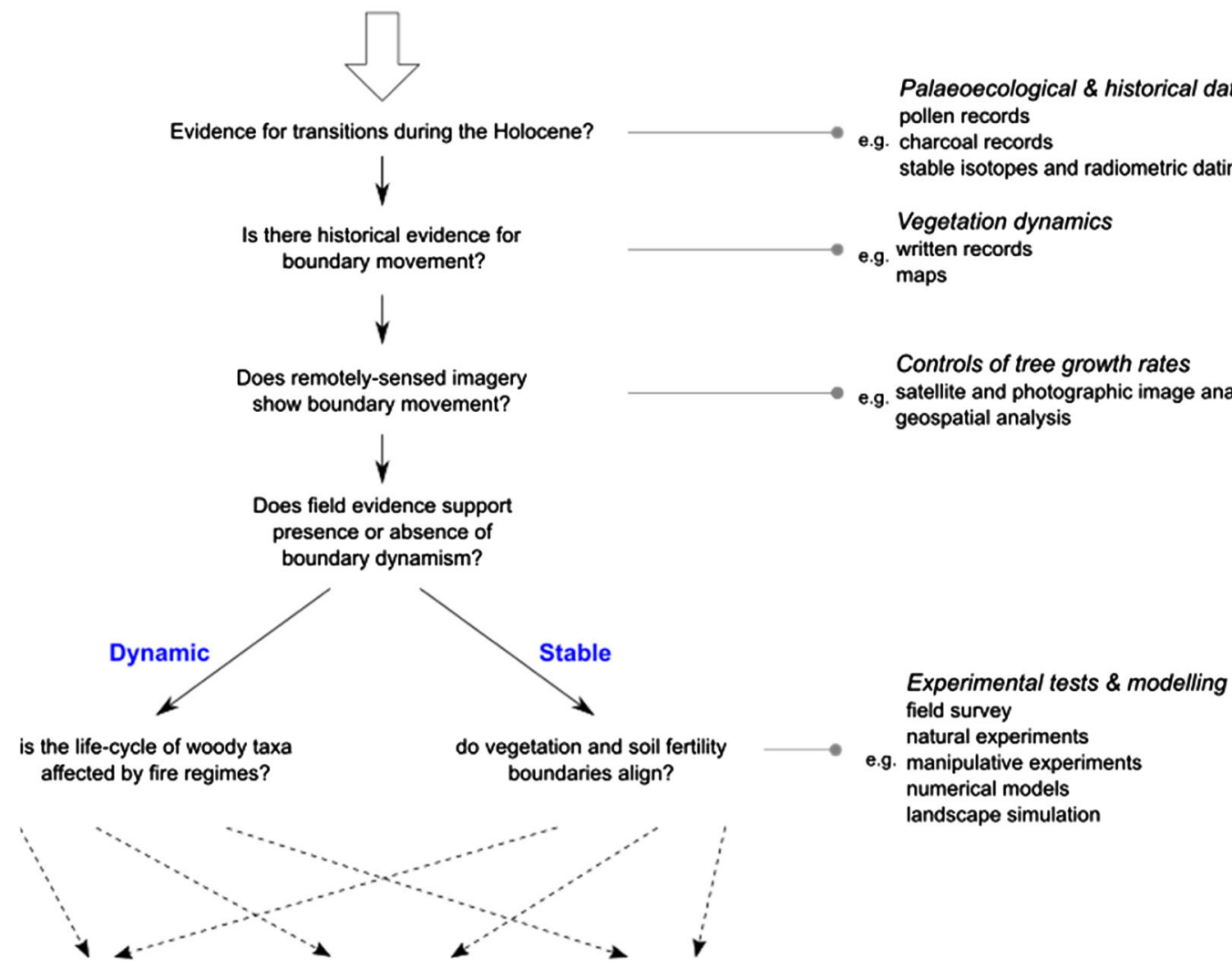

FIRE

INTERACTIVE

Fig. 6 A structured methodological pathway designed to identify the factors that control forest-savanna mosaics. The pathway comprises three stages that use different sources of information derived from palaeocological, historical ecological and landscape ecological studies to resolve whether boundaries observed in the landscape are dynamic. If the boundaries are dynamic then neoecological methods need to be applied to understand how fire

areas of the landscape where tree growth was sufficient to escape frequent fires. By contrast, their models suggested that the greatest fire activity occurred on the least fertile landscape settings, which supported flammable grasslands. The results of the modelling of Murphy et al. (2010) are therefore inconsistent with FMASS, instead pointing to a strong interaction between edaphic factors and the joint control of fire and vegetation patterns.

Should landscape analysis demonstrate a highly dynamic mosaic driven by fire, then targeted field sampling is required to describe the spatio-temporal
METHOD

Palaeoecological \& historical data

stable isotopes and radiometric dating

Vegetation dynamics

written records

Controls of tree growth rates

phic image analysis

field survey

numerical models

landscape simulation

\section{SOILS}

regimes affect the establishment and growth of woody taxa. If, on the other hand, the boundaries are stable, neo-ecological studies are required to understand how topo-edaphic soil factors can control woody taxa by inhibiting establishment and growth. The outcome of this structured methodological pathway should resolve whether fire, soils of interactions between them control woody vegetation distribution

dynamics of vegetation mosaics. For example, stand structural analysis is required to describe the temporal pattern of the invasion of savanna by forest taxa (e.g., continuously vs. episodically), and how tree invasion affects tree species composition and community-level flammability (MacDermott et al. 2016). Such analyses must control for soil type and landscape setting. For example, field surveys substantiated aerial photographic analysis that showed widespread invasion of rainforest trees into a tropical savanna following the cessation of Aboriginal landscape burning on fertile basalt islands and peninsulas in the north Kimberley, 
Australia (Ondei et al. 2017). These surveys, however, found limited expansion on sandstone landscapes, which suggests that in this region the FMASS model is context-dependent and potentially relevant only to highly fertile substrates.

The nexus between fire, vegetation and soil fertility must be established using fire-exclusion experiments (Pellegrini et al. 2015), a chronosequence approach (caveats of Johnson and Miyanishi 2008 notwithstanding) and natural experiments (Ondei et al. 2017). Tree growth, whether determined using dendrochronological techniques (Bowman et al. 2013) or via classical field and pot-trial experimentation, must be related to edaphic factors. Collectively, these data can be used in dynamic spatial models (such as that presented here) to determine if growth rates are sufficient to allow forest species to regenerate and escape the firetrap under some, but not all, fire frequencies.

We acknowledge that researchers have, in isolation, undertaken all of the steps outlined in our framework (Fig. 6); however, no single research program has yet combined them in the way we argue is necessary to demonstrate the presence of FMASS either in Tasmania or indeed elsewhere in the world. We do not underestimate the logistical challenges in conducting such an integrated program. However, an inferential weakness in the reliance on ad hoc studies is that their findings can be deemed as validating FMASS when other alternative explanations are equally plausible (i.e., confirmation bias).

It is important to acknowledge that our framework does not explicitly address the question of the origin of forest and savanna mosaics (Petraitis and Latham 1999). In many parts of the world there remains considerable controversy as to whether savannas are the result of anthropogenic fire-activity or arise independent of human fireuse (Willis et al. 2008; Bowman and Haberle 2010; McWethy et al. 2010), with some authors arguing that plant and animal species diversity can be used as evidence against human agency (Bond et al. 2008; Foreman 2016). In the case of Tasmanian sedgelands the diverse, and in some cases endemic, vascular (Corbett and Balmer 2007; Lawrence et al. 2007) and non-vascular (Kantvilas 2007) flora and vertebrate (Driessen 2007) and invertebrate (Driessen et al. 2014) fauna points to an ancient ecosystem that preceded human colonisation in the late-Pleistocene. An iconic example is provided by the endemic Tasmania crustacean species in the genera Ombrastacoides and Spinastacoides that have evolved a unique physiology enabling them to live in burrows in highly acid sedgelands soils (pH 4.5-3.5) (Richardson and Doran 2007). These crayfish are considered keystone species in sedgelands because they create macropores that affect soil drainage, and hence pedogensis, and provide habitat for a diverse fauna, including nematodes, oligochaetes, copepods, isopods and amphipods (Driessen 2007). Analyses that integrate palaeo-ecological and phylogenetic approaches of floral and faunal linages have demonstrated the antiquity of some savannas, and their existence independent of human-set landscape fires (e.g., Simon et al. 2009; Agarwal and Ramakrishnan 2017), and such research is required to understand the historical biogeography of the Tasmanian sedgelands.

\section{Conclusion}

The fire-mediated alternative stable state (FMASS) model of forest - savanna mosaics is attractive (even seductive) to landscape ecologists and biogeographers. At its heart, this model asserts that changes in fire regimes can overwhelm the physical environmental controls of vegetation, and, by extension, highlights the capacity of human fire-use to dramatically transform landscapes. Underpinning many variants of this model are fire-vegetation-soil (FVS) interactions that both drive state changes and stabilise vegetation mosaics. The landscapes of perhumid Tasmania are the locus of the earliest models of FMASS and FVS. However, more than 40 years of research in this region has not been able to convincingly discriminate between the dynamic FMASS and FVS models (Jackson 1968) and a model of stable vegetation boundaries controlled by soils and reinforced by fire (Mount 1979, 1982) (Table 1). We suspect that both the Jackson and Mount models apply in different localities in Tasmania because the interplay of fire, vegetation and soils is highly context-specific, especially influenced by geology, geomorphological setting, and ecohydrology. Such a conclusion accords with the findings of Ondei et al. (2017) who demonstrate widespread invasion of rainforest trees into fire protected tropical savanna on fertile basalt, but not on neighbouring infertile sandstone substrates. Thus, we caution against generalising findings from one landscape setting to an entire region, or indeed the globe.

Nonetheless the fire ecology of temperate landscapes of Tasmania has been drawn into debates about tropical forest - savanna landscape dynamics 
(e.g. Staal and Flores 2015). There are not close parallels between the systems of temperate Tasmania and tropical rainforest - savanna landscape mosaics. In Tasmania, combustible organic soils amplify fire-soilvegetation feedbacks, whereas tropical forest - savanna ecosystems typically occur on deeply weathered mineral soils. One important exception are tropical rainforests that occur on deep organic soils such as those on the island of Borneo. Recent research there has shown that the combination of ecohydrological drought (exacerbate by anthropogenic soil drainage) and fire can cause the state change from rainforest to shrubland because the upper profile of organic soils are destroyed (Bowman et al. 2017; Taufik et al. 2017). Also, unlike most tropical savannas (e.g., Skarpe 1992), no substantial populations of large herbivores graze on the Tasmanian sedgelands: whether the extinct Pleistocene marsupial megafauna (Gillespie et al. 2012) were important in shaping the ecology (e.g., Gill 2014; Rule et al. 2012) in this ecosystem is unknown.

Our exploratory simulation model suggests that under some circumstances FMASS and FVS models can result in forest - savanna mosaics. Based on our experience of tropical savannas and Tasmanian and New Zealand vegetation we suspect that where climate is favourable for forest most forest - savanna mosaics are the result of underlying edaphic factors, with human ignitions sharpening forest boundaries. One key exception is where human fires have destroyed forests and created savannas or grasslands (Cochrane et al. 1999; McGlone 2001; McWethy et al. 2010, 2014; Balch et al. 2015). In such 'derived savannas' (Backéus 1992), we suspect that firevegetation-soil feedbacks that cause hysteresis in the loss (fast) and recovery (slow) of forest, potentially exacerbated by seed dispersal limitation, are most likely to be of importance on infertile substrates where nutrient capital is build up in the organic soil horizons.

Our modelling also highlights the need for careful sampling because where edaphic factors control forest savanna mosaics there may still be small regions of boundary dynamism that, if sampled, can lead to erroneous support for FMASS. We provide a structured methodological pathway that would facilitate demonstration of fire-vegetation-soil interactions. Our approach demands methodological pluralism, and requires weaving together research across temporal and spatial scales using a diverse range of methodologies and statistical analyses that control for spatio-temporal autocorrelation, and, ideally, targeted experimentation (Bowman et al. 2015). We acknowledge that such an integrated program is challenging to implement and fund given the scale and scope of the research, and requires building a research team with the appropriate skill sets and shared philosophy. However, a continued reliance on ad hoc studies, and generalisations from poorly replicated, and typically correlative, analyses to support fire-mediated alternative stable states will sustain, rather than resolve, past and current debates about the reality of FMASS and the relevance of FVS interactions to this model of landscape dynamics in Tasmania, and indeed elsewhere in the world.

Acknowledgements DMJSB acknowledges his numerous collaborators who have shaped his understanding of fire driven landscape dynamics and fire-soil-vegetation, most particularly the late W.D. Jackson, whose ideas and insights have provided inspiration for over 40 years. GLWP is grateful for the support of a University of Tasmania Visiting scholar fellowship. Lynda Prior provided insightful feedback on an earlier draft of this paper, as did two anonymous referees.

\section{References}

Accatino F, Wiegand K, Ward D, De Michele C (2016) Trees, grass, and fire in humid savannas - the importance of life history traits and spatial processes. Ecol Model 320:135-144. https://doi.org/10.1016/j.ecolmodel.2015.09.014

Agarwal I, Ramakrishnan U (2017) A phylogeny of open-habitat lizards (Squamata: Lacertidae: Ophisops) supports the antiquity of Indian grassy biomes. J Biogeogr. https://doi. org/10.1111/jbi.12999

Backéus I (1992) Distribution and vegetation dynamics of humid savannas in Africa and Asia. J Veg Sci 3:345-356. https://doi.org/10.2307/3235759

Balch JK, Brando PM, Nepstad DC et al (2015) The susceptibility of southeastern Amazon forests to fire: insights from a largescale burn experiment. Bioscience 65:893-905. https://doi. org/10.1093/biosci/biv106

Balmer J (1990) Two moorland boundaries. Tasforests 2:133-141

Bankes S (1993) Exploratory modeling for policy analysis. Oper Res 41:435-449. https://doi.org/10.1287/opre.41.3.435

Batllori E, Ackerly DD, Moritz MA (2015) A minimal model of fire-vegetation feedbacks and disturbance stochasticity generates alternative stable states in grassland-shrubland-woodland systems. Environ Res Lett 10:034018. https://doi. org/10.1088/1748-9326/10/3/034018

Battersby PF, Wilmshurst JM, Curran TJ et al (2017) Exploring fire adaptation in a land with little fire: serotiny in Leptospermum scoparium (Myrtaceae). J Biogeogr 44: 1306-1318. https://doi.org/10.1111/jbi.12950

Beard JS (1953) The savanna vegetation of northern tropical America. Ecol Monogr 23:149-215. https://doi.org/10.2307 $/ 1948518$ 
Beckage B, Ellingwood C (2008) Fire feedbacks with vegetation and alternative stable states. Complex Syst 18:159-173

Beckage B, Platt WJ, Gross LJ (2009) Vegetation, fire, and feedbacks: a disturbance-mediated model of savannas. Am Nat 174:805-818

Behling H, Hooghiemstra H (2000) Holocene Amazon rainforest - savanna dynamics and climatic implications: highresolution pollen record from Laguna Loma Linda in eastern Colombia. J Quat Sci 15:687-695. https://doi.org/10.1002 /1099-1417(200010)15:7<687::AID-JQS551>3.0.CO;2-6

Billings WD, Mark AF (1957) Factors involved in the persistence of montane treeless balds. Ecology 38:140-142. https://doi. org/10.2307/1932138

Bond WJ, Woodward FI, Midgley GF (2005) The global distribution of ecosystems in a world without fire. New Phytol 165: 525-538. https://doi.org/10.1111/j.1469-8137.2004.01252.x

Bond WJ, Silander JA Jr, Ranaivonasy J, Ratsirarson J (2008) The antiquity of Madagascar's grasslands and the rise of $\mathrm{C}_{4}$ grassy biomes. J Biogeogr 35:1743-1758. https://doi. org/10.1111/j.1365-2699.2008.01923.x

Bowman DMJS (2000) Australian rainforests: islands of green in a land of fire. Cambridge University Press, Cambridge

Bowman D (2017) Ecohydrology: when will the jungle burn? Nat Clim Chang 7:390-391. https://doi.org/10.1038/nclimate3284

Bowman DMJS, Brown MJ (1986) Bushfires in Tasmania: a botanical approach to anthropological questions. Archaeol Ocean 21:166-171. https://doi.org/10.1002/j.18344453.1986.tb00145.x

Bowman DMJS, Haberle SG (2010) Paradise burnt: how colonizing humans transform landscapes with fire. Proc Natl Acad Sci 107:21234-21235. https://doi.org/10.1073 /pnas.1016393108

Bowman DMJS, Jackson WD (1981) Vegetation succession in Southwest Tasmania. Search 12:358-362

Bowman DMJS, Wood SW (2009) Fire driven land cover change in Australia and W.D. Jackson's theory of the fire ecology of southwest Tasmania. In Cochrane MA (ed) Tropical fire ecology: Climate change, land use and ecosystem dynamics. Springer-Praxis, Heidelberg, p 87-111

Bowman DMJS, Maclean AR, Crowden RK (1986) Vegetation-soil relations in the lowlands of south-west Tasmania. Aust J Ecol 11: 141-153. https://doi.org/10.1111/j.1442-9993.1986.tb01385.x

Bowman DMJS, Wood SW, Neyland D et al (2013) Contracting Tasmanian montane grasslands within a forest matrix is consistent with cessation of aboriginal fire management. Austral Ecology 38:627-638. https://doi.org/10.1111/aec.12008

Bowman DMJS, Perry GLW, Marston JB (2015) Feedbacks and landscape-level vegetation dynamics. Trends Ecol Evol 30: 255-260. https://doi.org/10.1016/j.tree.2015.03.005

Bowman DMJS, Williamson GJ, Abatzoglou JT et al (2017) Human exposure and sensitivity to globally extreme wildfire events. Nature Ecology \& Evolution 1:0058. https://doi. org/10.1038/s41559-016-0058

Brown MJ (1996) Benign neglect and active management in Tasmania's forests: a dynamic balance or ecological collapse? For Ecol Manag 85:279-289. https://doi.org/10.1016 /S0378-1127(96)03764-4

Brown M, Podger F (1982a) Floristics and fire regimes of a vegetation sequence from sedgeland-heath to rainforest at Bathurst harbour, Tasmania. Aust J Bot 30:659-676. https://doi.org/10.1071/BT9820659
Brown MJ, Podger F (1982b) On the apparent anomaly between observed and predicted percentages of vegetation types in south-west Tasmania. Austral Ecology 7:203-205. https://doi.org/10.1111/j.1442-9993.1982.tb01594.x

Brown MJ, Balmer J, Podger FD (2002) Vegetation change over twenty years at Bathurst harbour, Tasmania. Aust J Bot 50: 499-510. https://doi.org/10.1071/BT01037

Cochrane MA, Alencar A, Schulze MD et al (1999) Positive feedbacks in the fire dynamic of closed canopy tropical forests. Science 284:1832-1835. https://doi.org/10.1126 /science.284.5421.1832

Colhoun EA, Shimeld PW (2012) Late-quaternary vegetation history of Tasmania from pollen records. In: Haberle SG, David B (eds) Peopled landscapes: archaeological and biogeographic approaches to landscapes. ANU Press, Canberra, pp 297-328

Conedera M, Tinner W, Neff C et al (2009) Reconstructing past fire regimes: methods, applications, and relevance to fire management and conservation. Quat Sci Rev 28:555-576. https://doi.org/10.1016/j.quascirev.2008.11.005

Cook JM, Mark AF, Shore BF (1980) Responses of Leptospermum scoparium and L. ericoides (Myrtaceae) to waterlogging. N Z J Bot 18:233-246. https://doi.org/10.1080 /0028825X.1980.10426922

Corbett J, Balmer J (2007) Buttongrass moorland in Tasmania what and where? AustralasianPlant Conservation 16:3-5

Cosgrove R (1999) Forty-two degrees south: the archaeology of late Pleistocene Tasmania. J World Prehist 13:357-402. https://doi.org/10.1023/A:1022310029016

di Folco M-B, Kirkpatrick JB (2013) Organic soils provide evidence of spatial variation in human-induced vegetation change following European occupation of Tasmania. J Biogeogr 40: 197-205. https://doi.org/10.1111/j.1365-2699.2012.02779.x

Driessen M (2007) Buttongrass moorland fauna. Australas Plant Conserv 16:20-22

Driessen M, Mallick SA, Thurstans S, et al (2014) Distribution and conservation status of two endemic Tasmanian crustaceans, Allanaspides hickmani and Allanaspides helonomus (Syncarida: anaspididae). Papers and Proceedings of the Royal Society of Tasmania, 148:17-25

Ellis R (1985) The relationships among eucalypt forest, grassland and rainforest in a highland area in north-eastern Tasmania. Aust J Ecol 10:297-314. https://doi.org/10.1111/j.14429993.1985.tb00891.x

Ellis R, Graley A (1983) Gains and losses in soil nutrients associated with harvesting and burning eucalypt rainforest. Plant Soil 74:437-450. https://doi.org/10.1007/BF02181361

Falk DA, Heyerdahl EK, Brown PM et al (2011) Multi-scale controls of historical forest-fire regimes: new insights from fire-scar networks. Front Ecol Environ 9:446-454. https://doi.org/10.1890/100052

Fensham R, Kirkpatrick J (1992). The eucalypt forest grassland/ grassy woodland boundary in central Tasmania. Aust J Bot 40(2):123-138

Flannery TF (1994) The future eaters: an ecological history of the Australasian people. Reed Books, Sydney

Fletcher M-S, Thomas I (2007) Holocene vegetation and climate change from near Lake Pedder, south-west Tasmania, Australia. J Biogeogr 34:665-677. https://doi.org/10.1111 j.1365-2699.2006.01659.x 
Fletcher M-S, Thomas I (2010) The origin and temporal development of an ancient cultural landscape. J Biogeogr 37:21832196. https://doi.org/10.1111/j.1365-2699.2010.02363.x

Fletcher M-S, Wolfe BB, Whitlock C et al (2014a) The legacy of mid-Holocene fire on a Tasmanian montane landscape. $\mathrm{J}$ Biogeogr 41:476-488. https://doi.org/10.1111/jbi.12229

Fletcher M-S, Wood SW, Haberle SG (2014b) A fire-driven shift from forest to non-forest: evidence for alternative stable states? Ecology 95:2504-2513. https://doi.org/10.1890/12-1766.1

Foreman PW (2016) A framework for testing the influence of aboriginal burning on grassy ecosystems in lowland, mesic south-eastern Australia. Aust J Bot 64:626-642. https://doi. org/10.1071/BT16081

French BJ, Prior LD, Williamson GJ, Bowman DM (2016) Cause and effects of a megafire in sedge-heathland in the Tasmanian temperate wilderness. Aust J Bot 64:513-525. https://doi. org/10.1071/BT16087

Furley P (2010) Tropical savannas: biomass, plant ecology, and the role of fire and soil on vegetation. Prog Phys Geogr 34: 563-585. https://doi.org/10.1177/0309133310364934

Gammage B (2011) The biggest estate on earth: how aborigines made Australia. Allen \& Unwin, Crows Nest

Gill JL (2014) Ecological impacts of the late quaternary megaherbivore extinctions. New Phytol 201:1163-1169. https://doi.org/10.1111/nph.12576

Gillespie R, Camens AB, Worthy TH et al (2012) Man and megafauna in Tasmania: closing the gap. Quat Sci Rev 37: 38-47. https://doi.org/10.1016/j.quascirev.2012.01.013

Good P, Harper A, Meesters A et al (2016) Are strong firevegetation feedbacks needed to explain the spatial distribution of tropical tree cover?: what controls fire-induced tropical tree mortality? Glob Ecol Biogeogr 25:16-25. https://doi. org/10.1111/geb.12380

Harwood CE, Jackson WD (1975) Atmospheric losses of four plant nutrients during a forest fire. Aust For 38:92-99. https://doi.org/10.1080/00049158.1975.10674144

Henderson W, Wilkins CW (1975) The interaction of bushfires and vegetation. Search 6:130-133

Hill RS (1982) Rainforest fire in western Tasmania. Aust J Bot 30: 583. https://doi.org/10.1071/BT9820583

Hirota M, Holmgren M, Van Nes EH, Scheffer M (2011) Global resilience of tropical forest and savanna to critical transitions. Science 334:232-235. https://doi.org/10.1126/science.1210657

Hoffmann WA, Geiger EL, Gotsch SG et al (2012) Ecological thresholds at the savanna - forest boundary: how plant traits, resources and fire govern the distribution of tropical biomes. Ecol Lett 15:759-768. https://doi.org/10.1111/j.14610248.2012.01789.x

Horton DR (1982) The burning question: aborigines, fire and Australian ecosystems. Mankind 13:237-252. https://doi. org/10.1111/j.1835-9310.1982.tb01234.x

Iglesias V, Yospin GI, Whitlock C (2015) Reconstruction of fire regimes through integrated paleoecological proxy data and ecological modeling. Front Plant Sci 5:785. https://doi. org/10.3389/fpls.2014.00785

Jackson WD (1968) Fire, air, water and earth - an elemental ecology of Tasmania. Proceedings of the Australian Ecological Society 3:9-16

Jackson W (2000) Nutrient stocks in Tasmanian vegetation and approximate losses due to fire. Pap Proc R Soc Tasmania $134: 1-18$
Johnson CN (2016) Fire, people and ecosystem change in Pleistocene Australia. Aust J Bot 64:643-651. https://doi. org/10.1071/BT16138

Johnson EA, Miyanishi K (2008) Testing the assumptions of chronosequences in succession. Ecol Lett 11:419-431. https://doi.org/10.1111/j.1461-0248.2008.01173.x

Johnstone JF, Hollingsworth TN, Chapin FS, Mack MC (2010) Changes in fire regime break the legacy lock on successional trajectories in Alaskan boreal forest. Glob Chang Biol 16:12811295. https://doi.org/10.1111/j.1365-2486.2009.02051.x

Johnstone JF, Allen CD, Franklin JF et al (2016) Changing disturbance regimes, ecological memory, and forest resilience. Front Ecol Environ 14:369-378. https://doi.org/10.1002/fee.1311

Jones R (1969). Fire-stick farming. Australian Natural History 16(7): 224-228

Kantvilas G (2007) Lichens: an overlooked lilliput in Tasmania's buttongrass moorlands. Australas Plant Conserv 16:18-19

Kellman M (1975) Evidence for Late Glacial age fire in a tropical montane savanna. J Biogeogr 2:57-63. https://doi. org/10.2307/3038202

Kellman M (1984) Synergistic relationships between fire and low soil fertility in neotropical savannas: a hypothesis. Biotropica 16:158-160. https://doi.org/10.2307/2387850

Kettridge N, Turetsky MR, Sherwood JH et al (2015) Moderate drop in water table increases peatland vulnerability to post-fire regime shift. Sci Rep 5:8063. https://doi.org/10.1038/srep08063

Langan L, Higgins SI, Scheiter S (2017) Climate-biomes, pedobiomes or pyro-biomes: which world view explains the tropical forest - savanna boundary in South America? J Biogeogr. https://doi.org/10.1111/jbi.13018

Lawrence N, Balmer J, Storey D, Whinam J (2007) The conservation value and reservation status of the Tasmanian Buttongrass moorland vascular plant flora. Australas Plant Conserv 16:12-13

Lloyd J, Bird MI, Vellen L et al (2008) Contributions of woody and herbaceous vegetation to tropical savanna ecosystem productivity: a quasi-global estimate. Tree Physiol 28:451468. https://doi.org/10.1093/treephys/28.3.451

MacDermott HJ, Fensham RJ, Hua Q, Bowman DMJS (2016) Vegetation, fire and soil feedbacks of dynamic boundaries between rainforest, savanna and grassland. Austral Ecology n/a-n/a. https://doi.org/10.1111/aec.12415

Macphail MK (1979) Vegetation and climates in southern Tasmania since the last glaciation. Quat Res 11:306-341. https://doi.org/10.1016/0033-5894(79)90078-4

Macphail MK (1980) Natural regeneration processes in Tasmanian forests: a long-term perspective based on pollen analysis. Search 11:184-190

Macphail MK (2010) The burning question: Claims and counterclaims on the origin and extent of buttongrass moorland (blanket moor) insouthwest Tasmania during the present glacial-interglacial. In: Haberle SG, Stevenson J, Prebble M (eds) Altered Ecologies. Fire, Climate and Human Influence on Terrestrial Landscapes (Terra Australis 32). pp 323-339

Macphail MK, Pemberton M, Jacobson G (1999) Peat mounds of southwest Tasmania: possible origins. Aust J Earth Sci 46: 667-677. https://doi.org/10.1046/j.1440-0952.1999.00736.x

Magnusson WE, Sanaiotti TM, Lima AP et al (2002) A comparison of $813 \mathrm{C}$ ratios of surface soils in savannas and forests in Amazonia. J Biogeogr 29:857-863. https://doi.org/10.1046 j.1365-2699.2002.00674.x 
Mariani M, Connor SE, Fletcher M-S et al (2017) How old is the Tasmanian cultural landscape? A test of landscape openness using quantitative land cover reconstructions. J Biogeogr. https://doi.org/10.1111/jbi.13040

Mark AF, Smith PMF (1975) A lowland vegetation sequence in South Westland: Pakihi bog to mixed beech-podocarp forest. Part 1: the principal strata. Proc NZ Ecol Soc 22:76-92

Marsden-Smedley JB, Catchpole WR, Pyrke A (2001) Fire modelling in Tasmanian buttongrass moorlands. IV. Sustaining versus non-sustaining fires. Int J Wildland Fire 10:255-262. https://doi.org/10.1071/WF01026

May RM (1977) Thresholds and breakpoints in ecosystems with a multiplicity of stable states. Nature 269:471-477. https://doi. org/10.1038/269471a0

McGlone MS (1983) Polynesian deforestation of New Zealand: a preliminary synthesis. Archaeol Ocean 18:11-25

McGlone MS (2001) The origin of the indigenous grasslands of southeastern South Island in relation to pre-human woody ecosystems. N Z J Ecol 25:1-15

McGlone MS, Buitenwerf R, Richardson SJ (2016) The formation of the oceanic temperate forests of New Zealand. N Z J Bot 54: 128-155. https://doi.org/10.1080/0028825X.2016.1158196

McIntire EJB, Fajardo A (2009) Beyond description: the active and effective way to infer processes from spatial patterns. Ecology 90:46-56

McIntosh PD et al (2005) The role of fire and nutrient loss in the genesis of the forest soils of Tasmania and southern New Zealand. For Ecol Manag 220(1):185-215

McWethy DB, Whitlock C, Wilmshurst JM et al (2010) Rapid landscape transformation in South Island, New Zealand, following initial Polynesian settlement. Proc Natl Acad Sci 107:21343-21348. https://doi.org/10.1073 /pnas. 1011801107

McWethy DB, Higuera PE, Whitlock C et al (2013) A conceptual framework for predicting temperate ecosystem sensitivity to human impacts on fire regimes. Glob Ecol Biogeogr 22:900912. https://doi.org/10.1111/geb.12038

McWethy DB, Wilmshurst JM, Whitlock C et al (2014) A highresolution chronology of rapid forest transitions following Polynesian arrival in New Zealand. PLoS One 9:e111328. https://doi.org/10.1371/journal.pone.0111328

Miller GH, Fogel ML, Magee JW et al (2005) Ecosystem collapse in Pleistocene Australia and a human role in megafaunal extinction. Science 309:287-290. https://doi.org/10.1126/science.1111288

Mount AB (1979) Natural regeneration processes in Tasmanian forests. Search 10:180-186

Mount A (1982) Fire-cycles or succession in southwest Tasmania. Search 13:174-175

Murphy BP, Bowman DMJS (2012) What controls the distribution of tropical forest and savanna? Ecol Lett 15:748-758. https://doi.org/10.1111/j.1461-0248.2012.01771.x

Murphy BP, Paron P, Prior LD et al (2010) Using generalized autoregressive error models to understand fire-vegetationsoil feedbacks in a mulga-spinifex landscape mosaic. J Biogeogr 37:2169-2182. https://doi.org/10.1111/j.13652699.2010.02359.x

Murray T, Cosgrove R, Warner A (1990) The management of archaeological resources in forested areas: a research project funded by the Tasmanian Forest research council Inc. Aust Archaeol 81-83
O’Sullivan D, Perry GLW (2013) Spatial simulation: exploring pattern and process. Wiley, Chichester

Odion DC, Moritz MA, DellaSala DA (2010) Alternative community states maintained by fire in the Klamath Mountains, USA. J Ecol 98:96-105. https://doi.org/10.1111/j.13652745.2009.01597.x

Ogden J, Deng Y, Boswijk G, Sandiford A (2003) Vegetation changes since early Maori fires in Waipoua Forest, northern New Zealand. J Archeol Sci 30:753-767

Oliveras I, Malhi Y (2016) Many shades of green: the dynamic tropical forest - savannah transition zones. Philos Trans R Soc, B 371:20150308. https://doi.org/10.1098 /rstb.2015.0308

Ondei S, Prior LD, Williamson GJ et al (2017) Fire and cattle disturbance affects vegetation structure and rain forest expansion into savanna in the Australian monsoon tropics. J Biogeogr. https://doi.org/10.1111/jbi.13039

Pascoe B (2014) Dark emu: black seeds: agriculture or accident? Magabala Books, Broome

Pausas JG, Dantas V d L (2016) Scale matters: fire-vegetation feedbacks are needed to explain tropical tree cover at the local scale. Glob Ecol Biogeogr. https://doi.org/10.1111/geb.12562

Pellegrini AFA (2016) Nutrient limitation in tropical savannas across multiple scales and mechanisms. Ecology 97:313324. https://doi.org/10.1890/15-0869.1

Pellegrini AFA, Hedin LO, Staver AC, Govender N (2015) Fire alters ecosystem carbon and nutrients but not plant nutrient stoichiometry or composition in tropical savanna. Ecology 96:1275-1285. https://doi.org/10.1890/14-1158.1

Pemberton M (1988) Soil erosion between Birchs inlet and Elliott Bay, southwestern Tasmania. Pap Proc R Soc Tasmania 122:109-114

Perry GLW, Enright NJ (2002) Humans, fire and landscape pattern: understanding a maquis-forest complex, Mont do, New Caledonia using a spatial "state-and-transition" model. J Biogeogr 29:1143-1159. https://doi.org/10.1046/j.13652699.2002.00774.x

Perry GLW, Wilmshurst JM, McGlone MS, Napier A (2012) Reconstructing spatial vulnerability to forest loss by fire in pre-historic New Zealand. Glob Ecol Biogeogr 21:10291041. https://doi.org/10.1111/j.1466-8238.2011.00745.x

Perry GLW, Wheeler AB, Wood JR, Wilmshurst JM (2014a) A high-precision chronology for the rapid extinction of New Zealand moa (Aves, Dinornithiformes). Quat Sci Rev 105: 126-135. https://doi.org/10.1016/j.quascirev.2014.09.025

Perry GLW, Wilmshurst JM, McGlone MS (2014b) Ecology and longterm history of fire in New Zealand. N Z J Ecol 38:157-176

Petraitis PS (2013) Multiple stable states in natural ecosystems, First edn. Oxford University Press, Oxford

Petraitis PS, Latham EL (1999) The importance of scale in testing the origins of alternative community states. Ecology 80:429442. https://doi.org/10.2307/176623

Pickering M (1992) Archaeological resources in forest environments: results of a survey in North-western Tasmania. Tasforests 4:39-44

Pivello VR, Coutinho LM (1992) Transfer of macro-nutrients to the atmosphere during experimental burnings in an open cerrado (Brazilian savanna). J Trop Ecol 8:487-497. https://doi.org/10.1017/S0266467400006829

Podger F, Bird T, Brown M (1988) Human activity, fire and change in the forest at Hogsback plain, southern Tasmania. In: Frawley KJ, Semple NM (eds) Australia's ever changing 
forests. Department of Geography and Oceanography and Australian Defence Force Academy, Canberra, pp 119-140

Richardson AMM, Doran N (2007) The role of burrowing crayfish in Tasmanian sedgelands. Australas Plant Conserv 16:22-24

Rule S, Brook BW, Haberle SG et al (2012) The aftermath of megafaunal extinction: ecosystem transformation in Pleistocene Australia. Science 335:1483-1486. https://doi. org/10.1126/science. 1214261

Simon MF, Grether R, de Queiroz LP et al (2009) Recent assembly of the Cerrado, a neotropical plant diversity hotspot, by in situ evolution of adaptations to fire. Proc Natl Acad Sci 106: 20359-20364. https://doi.org/10.1073/pnas.0903410106

Skarpe C (1992) Dynamics of savanna ecosystems. J Veg Sci 3: 293-300. https://doi.org/10.2307/3235754

Staal A, Flores BM (2015) Sharp ecotones spark sharp ideas: comment on "structural, physiognomic and above-ground biomass variation in savanna - forest transition zones on three continents - how different are co-occurring savanna and forest formations?" by Veenendaal et al. (2015). Biogeosciences 12:5563-5566. https://doi.org/10.5194/bg12-5563-2015

Stahle LN, Whitlock C, Haberle SG (2016) A 17,000-year-long record of vegetation and fire from Cradle Mountain National Park, Tasmania. Front Ecol Evol 4:82. https://doi. org/10.3389/fevo.2016.00082

Staver AC, Levin SA (2012) Integrating theoretical climate and fire effects on savanna and forest systems. Am Nat 180:211224. https://doi.org/10.1086/666648

Staver AC, Archibald S, Levin SA (2011) The global extent and determinants of savanna and forest as alternative biome states. Science 334:230-232. https://doi.org/10.1126 /science.1210465

Taufik M, Torfs PJJF, Uijlenhoet R et al (2017) Amplification of wildfire area burnt by hydrological drought in the humid tropics. Nat Clim Chang. https://doi.org/10.1038 /nclimate 3280

Thomas I, Cullen P, Fletcher M-S (2010) Ecological drift or stable fire cycles in Tasmania: a resolution. In: Haberle SG, Stevenson J, Prebble M (eds) altered ecologies. Fire, climate and human influence on terrestrial landscapes (Terra Australis 32). Pp 341-352

Veenendaal EM, Torello-Raventos M, Feldpausch TR et al (2015) Structural, physiognomic and above-ground biomass variation in savanna - forest transition zones on three continents how different are co-occurring savanna and forest formations? Biogeosciences 12:2927-2951. https://doi. org/10.5194/bg-12-2927-2015

Warman L, Moles AT (2009) Alternative stable states in Australia's wet tropics: a theoretical framework for the field data and a field-case for the theory. Landsc Ecol 24:1-13. https://doi.org/10.1007/s10980-008-9285-9

Warman L, Bradford MG, Moles AT (2013) A broad approach to abrupt boundaries: looking beyond the boundary at soil attributes within and across tropical vegetation types. PLoS One 8:e60789. https://doi.org/10.1371/journal. pone. 0060789

Webb LJ (1964) An historical interpretation of the grass balds of the Bunya Mountains, south Queensland. Ecology 45:159162. https://doi.org/10.2307/1937117

Wilensky U (1999) NetLogo. Center for Connected Learning and Computer-Based Modeling. Northwestern University, Evanston

Williams PA, Courtney S, Glenny D et al (1990) Pakihi and surrounding vegetation in North Westland, South Island. J R Soc N Z 20:179-203. https://doi.org/10.1080 /03036758.1990.10426724

Willis KJ, Gillson L, Virah-Sawmy M (2008) Nature or nurture: the ambiguity of $\mathrm{C}_{4}$ grasslands in Madagascar. J Biogeogr 35:1741-1742. https://doi.org/10.1111/j.13652699.2008.01985.x

Wilmshurst JM, Anderson AJ, Higham TGF, Worthy TH (2008) Dating the late prehistoric dispersal of Polynesians to New Zealand using the commensal Pacific rat. Proc Natl Acad Sci 105:7676-7680. https://doi.org/10.1073/pnas.0801507105

Wilson CJ (1999) Effects of logging and fire on runoff and erosion on highly erodible granitic soils in Tasmania. Water Resour Res 35:3531-3546. https://doi.org/10.1029/1999WR900181

Wilson JB, Agnew ADQ (1992) Positive-feedback switches in plant communities. Adv Ecol Res 23:264-321. https://doi. org/10.1016/S0065-2504(08)60149-X

Wood SW, Bowman DMJS (2012) Alternative stable states and the role of fire-vegetation-soil feedbacks in the temperate wilderness of southwest Tasmania. Landsc Ecol 27:13-28. https://doi.org/10.1007/s10980-011-9677-0

Wood SW, Allen KJ, Hua Q, Bowman DMJS (2010) Age and growth of a fire prone Tasmanian temperate old-growth forest stand dominated by Eucalyptus regnans, the world's tallest angiosperm. Forest Ecology and Management 260:438-447

Wood SW, Murphy BP, Bowman DMJS (2011a) Firescape ecology: how topography determines the contrasting distribution of fire and rain forest in the south-west of the Tasmanian wilderness world heritage area. J Biogeogr 38:1807-1820. https://doi.org/10.1111/j.1365-2699.2011.02524.x

Wood SW, Hua Q, Bowman DMJS (2011b) Fire-patterned vegetation and the development of organic soils in the lowland vegetation mosaics of south-west Tasmania. Australian Journal of Botany 59:126-136

Wood SW, Ward C, Bowman DMJS (2016) Substrate controls growth rates of the woody pioneer Leptospermum lanigerum colonizing montane grasslands in northern Tasmania. Austral Ecology n/a-n/a. https://doi.org/10.1111/aec.12390

Zinck RD, Grimm V (2008) More realistic than anticipated: a classical forest-fire model from statistical physics captures real fire shapes. The Open Ecology Journal 1:8-13. https://doi.org/10.2174/1874213000801010008 